\title{
Extrahepatic metastases as initial manifestations of hepatocellular carcinoma: an Egyptian experience
}

\author{
Thanaa El. A. Helal', Nehal A. Radwan ${ }^{1 *}$ and Mohamed Shaker ${ }^{2}$
}

\begin{abstract}
Background: The incidence of hepatocellular carcinoma (HCC) in Egypt has markedly increased in the recent years, mainly due to the high incidence of hepatitis $\mathrm{C}$ virus (HCV) infection. Consequently, the frequency of metastatic HCC has also increased. The current study presents a series of 47 patients who were initially diagnosed as metastatic HCC.

Methods: Forty seven patients with the diagnosis of extrahepatic metastases of HCC at initial presentation were included in the study. The sites of metastases were bones (17), lymph nodes (9), soft tissue (7), omentum (7), maxillary sinus (2), adrenal gland (2), brain (2) and skin (1). The diagnosis of metastatic HCC was confirmed by immunohistochemistry.

Results: The patients included in the study were 38 males and 9 females, ranging from 40 to 80 years (median 60 years). All patients were HCV-positive and 36 were cirrhotic. The diagnosis of primary HCC was confirmed in all cases, based on the typical hypervascular radiological features and/or high serum a-fetoprotein concentration, or histologic examination of liver biopsy.

Conclusion: Metastasis of HCC should be put into consideration when evaluating metastatic carcinoma with unknown primary. This is of particular importance in the Egyptian population who has the highest prevalence of HCV infection in the world.
\end{abstract}

Keywords: Hepatocellular carcinoma, Metastases, Initial presentation, Immunohistochemistry

\section{Background}

The incidence of hepatocellular carcinoma (HCC) shows a significant geographic variation worldwide. In Southeast Asia and Sub-Saharan Africa, the incidence is more than $15 / 100.000$ population per year due to the high prevalence of chronic hepatitis B virus (HBV) infection and chronic hepatitis $\mathrm{C}$ virus (HCV) infection [1]. Although HCC has been relatively uncommon in the Western countries, recent evidence shows an increasing rate in these areas [2-4]. In Egypt, hospital-based studies have reported that the annual proportion of HCC showed a significant rising trend from $4 \%$ in 1993 to $7 \%$ in 2002 of chronic liver disease patients [5]. This high incidence of HCC in Egypt is explained

\footnotetext{
* Correspondence: neharadwan@yahoo.com

${ }^{1}$ Departments of Pathology, Faculty of Medicine, Ain Shams University, Ramses Street- New Faculty Bldg. -5th floor, P.O. \# 11566 Cairo, Egypt
} Full list of author information is available at the end of the article by the increasing prevalence of $\mathrm{HCV}$ infection [6]. Unfortunately, Egypt has the highest prevalence of $\mathrm{HCV}$ infection in the world with $13.8 \%$ of the population infected [7].

Extrahepatic metastatic spread of HCC occurs in about $50 \%$ of cases, most often to the lungs, lymph nodes and bones [8]. The clinical presentations of patients with HCC were mostly concerned with the manifestations of the primary tumor and the metastatic presentation is a later event [9]. In the recent years, the metastatic behavior of $\mathrm{HCC}$ has shown two interesting new features. First, is the spread to unusual sites as soft tissue $[10,11]$, maxillary sinus [12] and orbit [13]. Second, is the identification of the metastatic lesion before the primary one is diagnosed [14-18].

Budhu et al. [19] have reported that many of the metastasis-promoting genes are embedded in the primary

\section{Biomed Central}


tumors and that the ability to metastasize may be an inherent quality of the tumor from the beginning. The condition of the liver parenchyma, the degree of viral hepatitis mediated liver damage and the genetic makeup of individuals may have a significant role to play in the development of metastases. Accordingly, it is possible that the geographic variation in the gene expression profile of liver parenchyma among HCC patients and/or the differences in the genetic makeup among populations may lead to epidemiologic variations in the metastatic behavior of HCC. This concept stimulates us to investigate a cohort of Egyptian patients who were initially presented with extrahepatic metastases.

The value of this work is bifold: first, it includes a relatively large number of cases who initially presented with metastatic HCC before the diagnosis of primary HCC was established. Similar studies are available in the literature only as case reports or case series except for four studies [14, 20-22]. Second, this study included Egyptian patients; all of whom were HCV-positive. To our knowledge, no similar reports are available in the literature.

\section{Methods}

A total of 47 cases, pathologically confirmed as metastatic $\mathrm{HCC}$ at initial presentation with no known liver primaries were retrieved retrospectively from the files of the pathology departments at Ain Shams University hospitals during the period 2001-2010. The medical records of these patients were examined to collect all relevant clinical, radiological and laboratory data. According to the metastatic site; these cases were categorized as follows:

\section{- Bone metastases (17 cases)}

The most common site of bone metastases was the ribs (6 cases) followed by the mandible (4 cases). The remaining cases were located in the humerus, femur, iliac bone and vertebral bodies (Fig. 1) (one or two cases for each site). They were clinically and radiologically suspected as primary or secondary malignant neoplasm. Biopsies were taken from all lesions.

- Lymph node metastases (9 cases)

Six cases were located in the abdominal lymph nodes and 3 were situated in the retroperitoneal, inguinal and supraclavicular lymph nodes. Guided needle or excisional biopsies from these sites were performed.

- Soft tissue metastases (7 cases)

These metastases were located in the anterior chest wall (4 cases), shoulder (1 case), back, deep to angle of scapula (1 case) and forearm (1 case). CT scan revealed a large soft tissue mass with no underlying

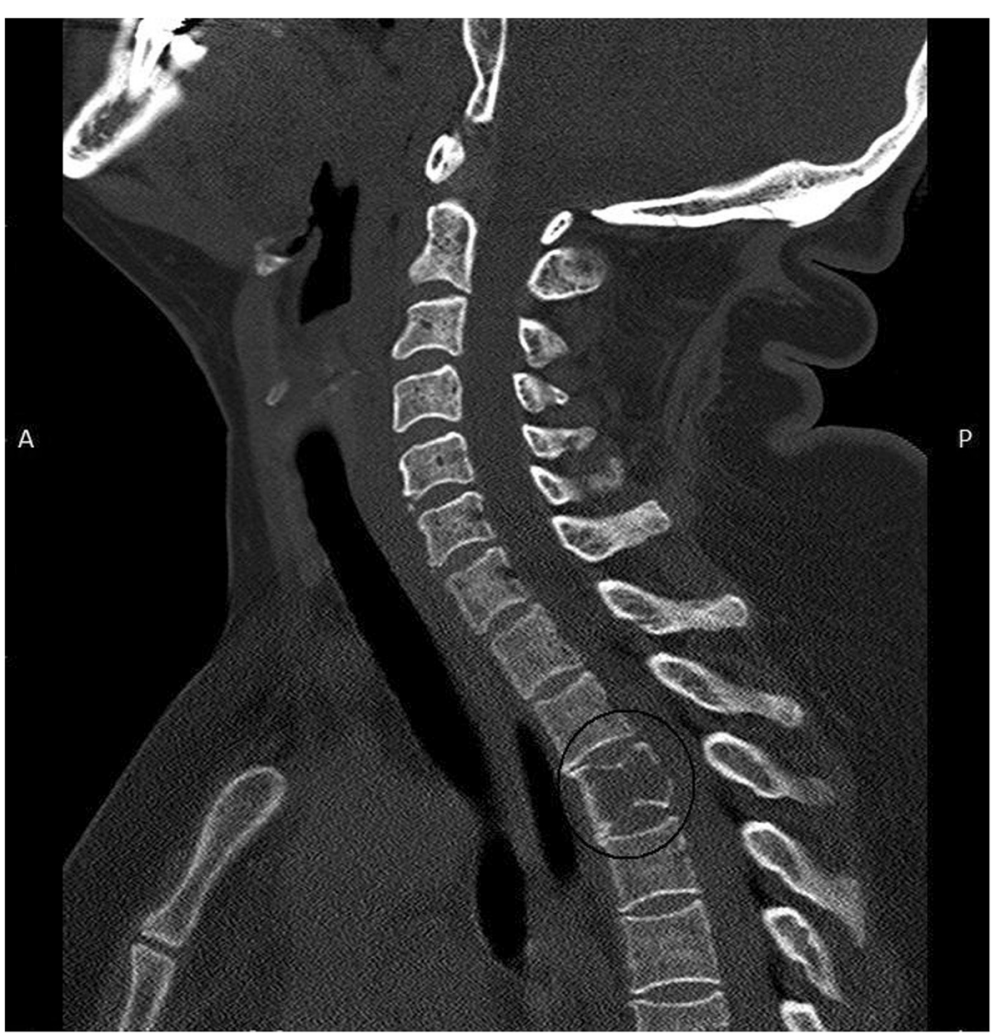

Fig. 1 Computed tomography (sagittal reconstruction) showing metastatic mass from HCC infiltrating body of third dorsal vertebra (circle) 
bone destruction. Needle biopsies were taken for pathological assessment.

- Omental metastases (7 cases)

The main complaint of these cases was abdominal pain, CT scan showed hypoechoic solitary mass in 2 patients and multiple nodules in 5 patients.

- Adrenal gland metastases (2 cases)

The patients presented with lumbar pain. Abdominal ultrasound detected a retroperitoneal mass close to the kidney. CT scan with contrast was done and revealed an enhancing adrenal mass from which needle biopsy was taken.

- Brain metastases (2 cases)

Both patients complained of headache and vomiting, CT scan showed a space occupying lesion in the left parietal lobe and right fronto-temporal area with homogeneous enhancement. Craniotomy was done and the tumor was excised.

- Maxillary sinus metastases (2 cases)

One of the two patients presented with severe bleeding after tooth extraction. The other had felt pain on occlusion and movement of the right upper molar, CT examination of both cases revealed soft tissue density infiltrating the adjacent bones and muscles.

- Skin metastases (1 case)

One patient presented with a cutaneous non ulcerating nodule on his hand. Radiography and CT scan of the hand suggested a subcutaneous metastasis.

\section{Histologic and immunohistochemical examination}

Tissue biopsies from all 47 patients were examined by the conventional Hematoxylin and Eosin (H\&E) staining method. Paraffin embedded tissue sections were also processed for immunohistochemistry using standard labeled streptavidin- biotin-peroxidase complex technique. Briefly, tissue sections were deparaffinized and hydrated in xylene and descending grades of alcohol. Antigen retrieval was performed by treating the tissue sections with citrate buffer, $\mathrm{pH} 6.0$ for $10 \mathrm{~min}$ in a $700-\mathrm{W}$ microwave oven. The endogenous peroxidase activity was blocked by incubating the slides in $3 \%$ hydrogen peroxide for $5-10 \mathrm{~min}$. This is followed by incubation with the primary antibody (hepatocyte paraffin antigen-1 (HepPar-1), $\alpha$ fetoprotein (AFP), CD34, CK7 and CK20 (Table 1)). The antibody reaction was detected with the avidin-biotin detection kit using diaminobenzidine (DAB) as chromogen. Proper positive control was applied, while negative control was done using the same tissues, omitting the primary antibody. HepPar -1 is known as one of the most specific and sensitive markers for HCC [23]. AFP is also a specific marker of HCC [24].

\section{Retrograde data collection}

When the diagnosis of metastatic HCC was confirmed by immunohistochemistry in all 47 patients included in the study, the data base of those patients were reviewed to investigate for the presence of primary HCC. The following data were collected:

- Clinical data: Patients age, gender, history of liver disease, presence of hepatomegaly or other manifestations of HCC.

- Radiologic data: Abdominal ultrasonography and/or CT were performed.

- Laboratory data: Serum AFP level as measured by radioimmunoassay (cut off level $20 \mathrm{ng} / \mathrm{ml}$ ), hepatitis B surface antigen (HBsAg), hepatitis $\mathrm{C}$ antibody and serum virus $C$ RNA which was detected by real time PCR.

Finally, the diagnosis of primary HCC was based on the presence of hepatic focal lesion(s) with typical hypervascular radiological features and/or high serum AFP level or pathologic examination of liver biopsy [21]. The study was carried out with full local ethics approval.

\section{Results}

The current study included 38 males and 9 females with M: F ratio 4.2:1. Their ages ranged from 40 to 80 years (median 60 years). The characteristics of the 47 patients are given in Table 2.

Table 1 Primary antibodies used for immunohistochemistry in the current study

\begin{tabular}{llllll}
\hline Antibody & Code no. & Dilution & Type & Company & Country \\
\hline HepPar-1 & MS-18100-R7 & Ready to use & Monoclonal Mouse & Lab Vision & CA, USA \\
AFP & A 0008 & $1: 400-1: 800$ & Polyclonal rabbit & Dako & Denmark \\
CD34 & M7165 & $1: 50$ & Monoclonal Mouse & Dako & Denmark \\
CK7 & M7018 & $1: 100$ & Monoclonal Mouse & Dako & Denmark \\
CK20 & M7019 & $1: 50$ & Monoclonal Mouse & Dako & Denark
\end{tabular}

HepPar-1 hepatocyte paraffin antigen-1, AFP a fetoprotein 
Table 2 Characteristics of 47 hepatocellular carcinoma patients with initial extrahepatic metastases

\begin{tabular}{|c|c|c|}
\hline & Number & Percent \\
\hline Male/Female & $38 / 9$ & \\
\hline Age range & $40-80$ years & \\
\hline Median age & 60 years & \\
\hline $\mathrm{HCV}$ & 47 & 100 \\
\hline HBV & 1 & 2.1 \\
\hline Elevated AFP & 22 & 46.8 \\
\hline Cirrhosis & 36 & 76.6 \\
\hline \multicolumn{3}{|l|}{ Hepatic focal lesion: } \\
\hline -Solitary & 38 & 80.9 \\
\hline -Multiple & 9 & 19.1 \\
\hline \multicolumn{3}{|l|}{ Site of metastases: } \\
\hline - Bones & 17 & 36.2 \\
\hline -Lymph nodes & 9 & 19.1 \\
\hline - Soft tissue & 7 & 15 \\
\hline - Omentum & 7 & 15 \\
\hline -Maxillary sinus & 2 & 4.2 \\
\hline -Adrenal gland & 2 & 4.2 \\
\hline -Brain & 2 & 4.2 \\
\hline -Skin & 1 & 2.1 \\
\hline \multicolumn{3}{|l|}{ Pattern of HCC growth : } \\
\hline -Trabecular (plate like) & 8 & $17 \%$ \\
\hline - Pseudoglandular (acinar) & 2 & $4.3 \%$ \\
\hline -Solid & 10 & $21.3 \%$ \\
\hline -Mixed patterns & 27 & $57.4 \%$ \\
\hline \multicolumn{3}{|l|}{ Grade: } \\
\hline - Well differentiated & 0 & $0 \%$ \\
\hline - Moderately differentiated & 17 & $36.2 \%$ \\
\hline - Poorly differentiated & 30 & $63.8 \%$ \\
\hline
\end{tabular}

$H C V$ hepatitis $C$ virus, $H B V$ hepatitis B virus, AFP a fetoprotein

- Clinical findings: All 47 patients had no clinical features suggestive of HCC. Their initial presentation was in the form of extrahepatic mass lesion as described in the material and methods.

- Radiologic examination of the liver: Thirty six patients (76.6 \%) had cirrhosis. Hepatic focal lesions were detected in all patients. These lesions were solitary in 38 patients $(80.9 \%)$ ranging from $8 \mathrm{~mm}$ to $2.5 \mathrm{~cm}$ in diameter. The remaining 9 patients, $(19.1 \%)$ had multiple focal lesions varying between $5 \mathrm{~mm}$ and $1.5 \mathrm{~cm}$.

- Laboratory findings: All patients were positive for $\mathrm{HCV}$ by real time PCR and one patient was also positive for hepatitis B virus antigen. Twenty two of the 47 patients (46.8 \%) showed elevated serum AFP level.
- Histology: All metastatic lesions showed malignant tumor tissue which consists of large hepatocyte-like cells with moderate nuclear atypia and prominent mitotic activity. The cells are mostly arranged in trabecular or sinusoidal pattern, which is very reminiscent to that seen in primary HCC (Fig. 2). So, the histologic diagnosis was metastatic carcinoma of possible hepatocellular origin.

- Immunohistochemistry: In all cases, the tumor cells showed granular cytoplasmic positivity for HepPar-1 (Fig. 3) and/or AFP (Fig. 4). For HepPar-1, the staining was diffuse and strong in 28(59.6\%) cases while AFP revealed focal and weak staining in 15 (32\%) cases. CD34 highlighted the rich vasculature of the tumor tissue and staining of the sinusoidal endoethelial cells. Staining for CK7 and CK20 yielded negative results (Fig. 5).

\section{Discussion}

Population-based cancer registry in Egypt reported that the incidence of HCC in Gharbiah (one of the Egyptian provinces) in the period from 1999 to 2003 was 3.5 times higher than that reported in the United States [25]. These data indicate that HCC represents a major health problem in Egypt and emphasize the importance of enhancing the early detection programs of primary HCC. In this context, we should be aware that about $5 \%$ of HCC may be presented as extrahepatic metastases for the first time [21, 24].

The primary purpose of the present work was to include a relatively large number of cases who initially presented with metastatic HCC before the diagnosis of primary $\mathrm{HCC}$ was established. By reviewing the literature, we found that nearly all publications on HCC diagnosed initially as extrahepatic metastases are case reports or case series except for four studies [14, 20-22] (Table 3). Most importantly, the current study included Egyptian patients; all of whom were HCV-positive. To our knowledge, no similar reports are available in the literature.

The largest series included 20 Chinese patients presented with bone metastases [20]. Another large study of 251 patients with extrahepatic metastases, at initial diagnosis of HCC was performed in Korea [21]. However, this study was concerned with the therapeutic modalities and clinical outcome of the studied patients. No immunohistochemistry was performed. The current study applied 5 antibodies for the immunohistochemical confirmation of the diagnosis. Moreover; all HCC patients included in our work were HCV-related as compared to the Korean study which included a heterogeneous group of HCC patients, related to HBV, HCV, alcohol or others. Variations in the etiology of HCC may have an impact on its metastatic behavior. 


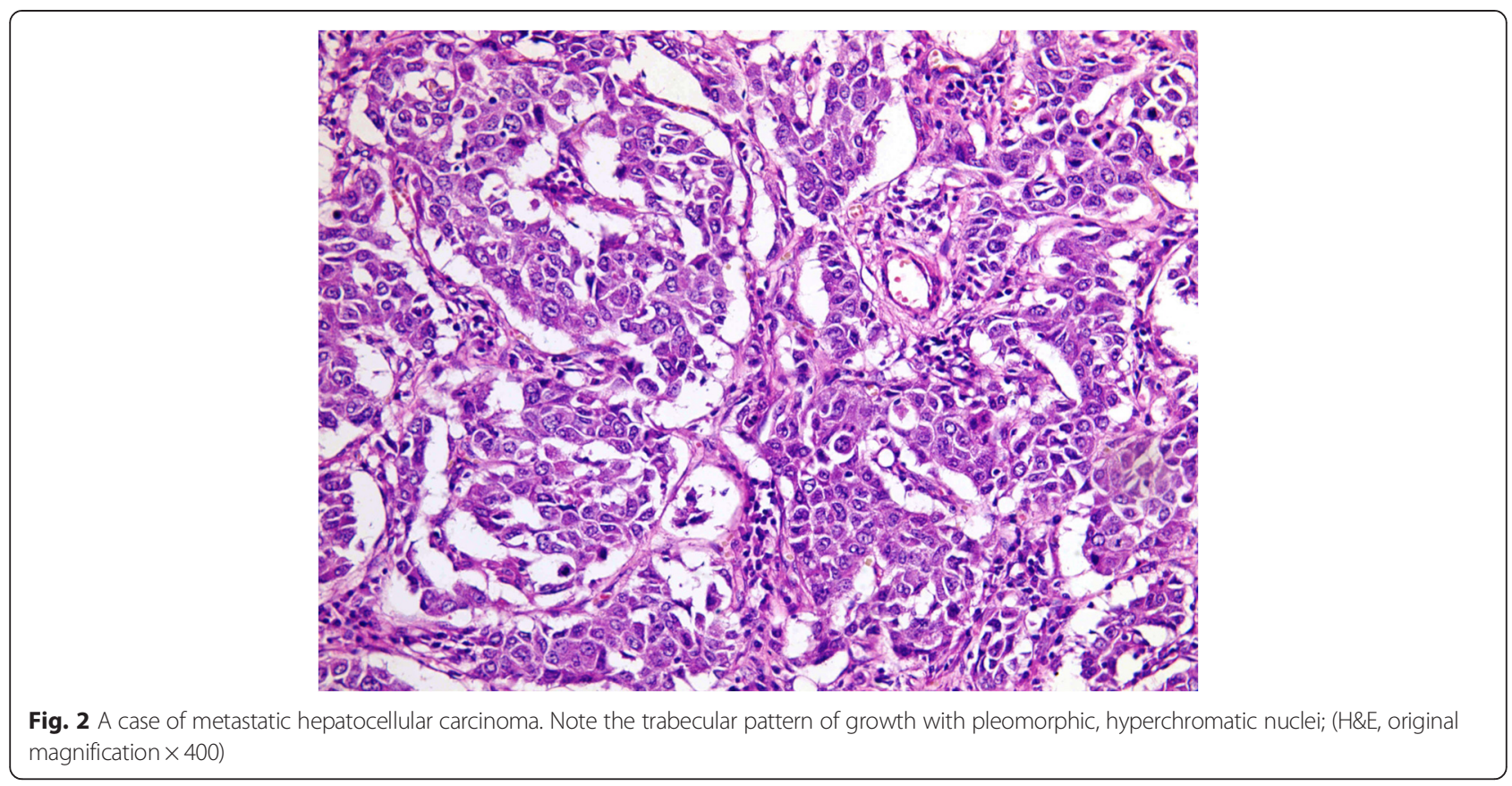

The present study included 47 cases with HCC who were initially presented by extrahepatic metastases. This number constitutes about $6.5 \%$ of the total number of HCC cases encountered during the period 2001-2010 (Total number of HCC cases $=720$ ). This percentage approximated that of Yoo et al. [21] who obtained a ratio of 5.4\%.

Furthermore; in our study, the male to female ratio was 4.1:1 and the median age was 60 years. This gender and age distribution is similar to that reported for primary HCC in Egypt [25]. On the other hand, the gender distribution in our study approximates that found in the aforementioned Asian reports [20, 21]. Nevertheless, the median age in both studies was 50 years which is 10 years earlier than that found in the current study. The older age of our patients may be attributed to the fact that all of them were HCV-associated. HCV-related HCC usually occurs after the development of cirrhosis. The average time from infection to onset of cirrhosis is $13-25$ years and time to onset of liver cancer is $17-31$ years [26].

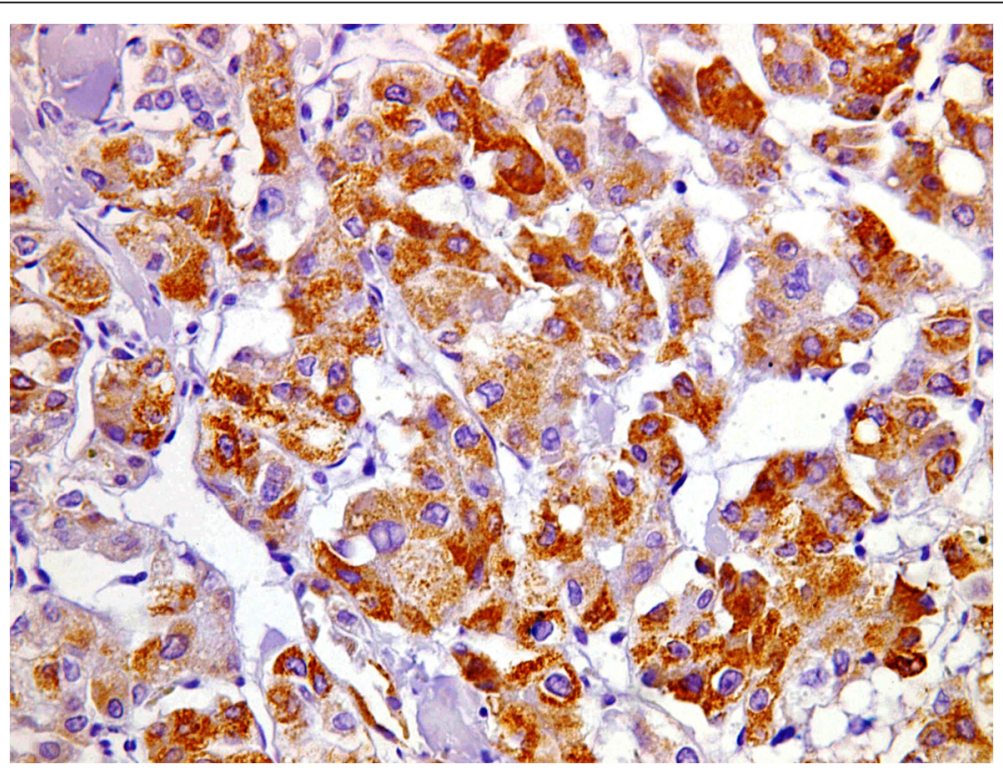

Fig. 3 A case of metastatic hepatocellular carcinoma with strong and diffuse cytoplasmic positivity for HepPar-1;(immuoperoxidase, original magnification $\times 400)$ 


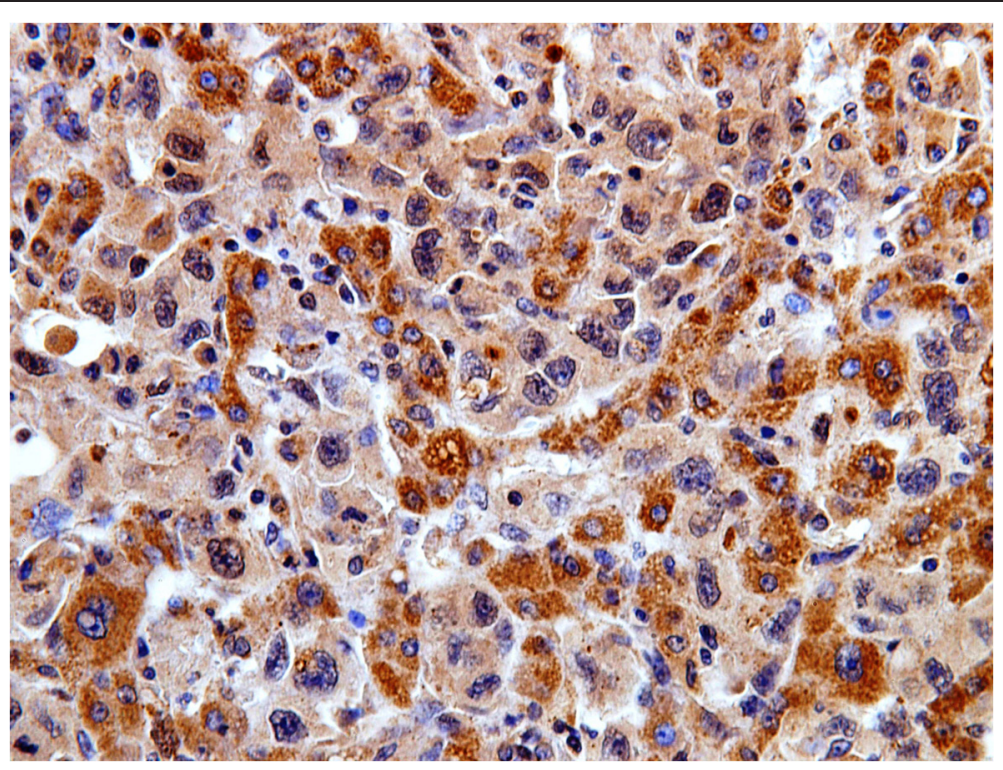

Fig. 4 A case of metastatic hepatocellular carcinoma with positive cytoplasmic immunostaining for AFP;(immuoperoxidase, original magnification $\times 400$ )

Most of the studies evaluating the sites of metastases of HCC did not differentiate between those occurring in patients already diagnosed as having primary HCC and other cases in whom metastases were the initial presentation with silent primary HCC [22, 27-29]. Fukutomi et al. [30] reported that the incidence of bone metastases from HCC is estimated to be $2-16 \%$ depending on the prevalence of the primary disease in the population.

In the current series, the most common site of metastasis was the skeleton (36.2\%), followed by lymph nodes (19.1\%). This contrasts with the results of Yoo et al. [21] who found that lymph node and bone metastases were detected in 37.5 and $18 \%$ of their cases respectively. This difference may be due to variation in patient selection. Alternatively, this contrast between our findings and those of Yoo et al. may reflect differences in the genetic profile and biologic behavior of Egyptian and Asian patients with HCC. In fact, the higher frequency of bone metastases as compared to lymph node metastasis in the present study was expected because of the high vascularity of HCC and the liver itself [31]. Last but not least, it is important to refer to the report of Olubuyide [32] who claimed that the pattern of metastases of HCC from the cirrhotic liver is different from that of

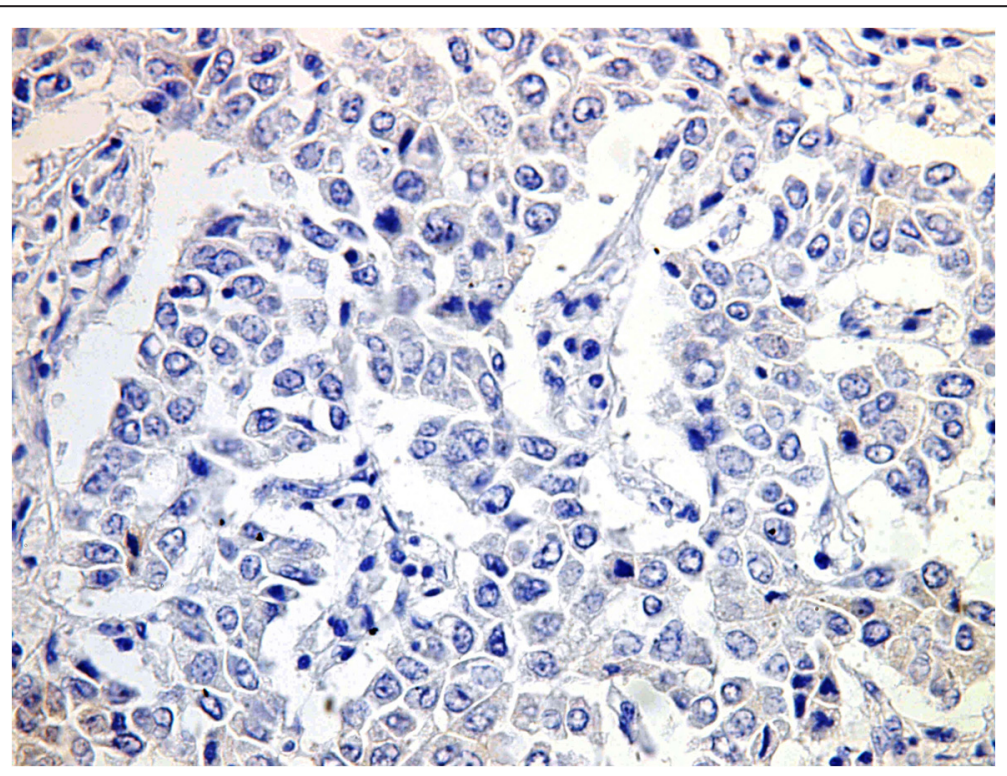

Fig. 5 A case of metastatic hepatocellular carcinoma with negative immunostaining for CK 20;(immuoperoxidase, original magnification $\times$ 400) 
Table 3 Summary of reported cases of hepatocellular carcinoma initially presented with extrahepatic metastases

\begin{tabular}{|c|c|c|c|c|c|c|}
\hline Authors name & $\begin{array}{l}\text { Year of } \\
\text { publication }\end{array}$ & $\begin{array}{l}\text { No of } \\
\text { patients }\end{array}$ & $\begin{array}{l}\text { Age range } \\
\text { (Median) }\end{array}$ & Male/Female & $\begin{array}{l}\text { Pattern of growth } \\
\text { of HCC }\end{array}$ & Metastatic anatomic region \\
\hline Liaw et al. [20] & 1989 & 20 & $26-64(50)$ & $16 / 4$ & $\begin{array}{l}\text { Predominantly trabecular } \\
\text { pattern }\end{array}$ & $\begin{array}{l}\text { Spines, ribs, skull, scapula, pelvis, } \\
\text { long bone, sternum, clavicle. }\end{array}$ \\
\hline Uka et al. [22] & 2007 & 151 & $21-82(64)$ & $117 / 34$ & Not mentioned & $\begin{array}{l}\text { Lung, lymph nodes, bones, } \\
\text { adrenal gland, peritoneum, } \\
\text { pancreas, nasal passages. }\end{array}$ \\
\hline Yoo et al. [21] & 2011 & 251 & $18-85(51)$ & $212 / 39$ & Not mentioned & $\begin{array}{l}\text { Lung, lymph node, bones, } \\
\text { adrenal gland, others. }\end{array}$ \\
\hline $\begin{array}{l}\text { The present } \\
\text { study }\end{array}$ & 2015 & 47 & $40-80(60)$ & $38 / 9$ & Predominantly mixed pattern & $\begin{array}{l}\text { Bones, lymph nodes, soft tissue, } \\
\text { omentum, maxillary sinus, } \\
\text { adrenal gland, brain, skin. }\end{array}$ \\
\hline
\end{tabular}

non-cirrhotic liver i.e. HCC from cirrhotic liver has few skeletal metastases. Since about $70 \%$ of our cases were cirrhotic, this speculation of Olubuyide seems not compatible with our results.

By collecting the metastases to the oro-maxillofacial region in the current study, they were totally 6 cases (4 mandible and 2 maxillary sinus). This finding supports the previous reports that documented the high frequency of HCC metastatic to the head and neck region as an initial presentation of the disease [33, 34].

Metastatic HCC to the oro-maxillofacial region is generally believed to occur via the lung [35]. However, all our 6 cases with oro-maxillofacial metastases did not have lung metastases by diagnostic imaging. It has been suggested that metastases could occur without lung metastases either by vertebral and azygos vein system or by lymphatic system. Spread via the former route is the preferable one in case of liver cirrhosis [36]. Since all 6 cases with oromaxillofacial metastases had liver cirrhosis, metastasis by vertebral vein system seems more likely.

\section{Conclusions}

In conclusion, the current study underscores that pathologists and surgeons, especially orthopedic and head and neck surgeons, must be prepared to consider the possibility of metastatic HCC higher on the list of their differential diagnosis. We also emphasize the importance of adding HepPar-1 and AFP to the panel of immunohistochemical markers applied for identification of the primary site of metastatic carcinoma. This is of particular importance in our country which has a very high incidence of HCC.

\section{Abbreviations}

HCC: Hepatocellular carcinoma; HBV: Hepatitis B virus; HCV: Hepatitis C virus; CT: Computed tomography; H\&E: Hematoxylin and Eosin; HepPar-1: Hepatocyte paraffin antigen-1; AFP: a fetoprotein; HBsAg: Hepatitis B surface antigen.

\section{Competing interests}

The authors declare that they have no competing interests.

\section{Authors' contributions}

TEAH conceived, designed and coordinated the study, evaluated immunohistochemistry, and drafted the manuscript. NAR performed data collection, reviewed the histological diagnosis, evaluated immunohistochemistry, carried out photographing and participated in the study design. MS carried out the radiological examination of all cases. All authors read and approved the final manuscript.

\section{Acknowledgement}

We thank our colleagues at Pathology department, Faculty of Medicine, Ain- Shams University for providing us with slides of some cases of metastatic hepatocellular carcinoma.

\section{Author details}

${ }^{1}$ Departments of Pathology, Faculty of Medicine, Ain Shams University, Ramses Street- New Faculty Bldg. -5th floor, P.O. \# 11566 Cairo, Egypt. ${ }^{2}$ Departments of Radiology, Faculty of Medicine, Ain Shams University, Ramses Street- Radiology department, Ain Shams University Hospital, P.O. \# 11566 Cairo, Egypt.

Received: 24 February 2015 Accepted: 3 June 2015

Published online: 30 June 2015

\section{References}

1. Mazzanti R, Gramantieri L, Bolondi L. Hepatocellular carcinoma.epidemiology and clinical aspects. Mol Aspects Med. 2008;29:130-43.

2. Jemal A, Siegel R, Ward E, Hao Y, Xu J, Murray T, et al. Cancer statistics. CA Cancer J Clin. 2008;58:71-96.

3. Altekruse SF, McGlynn KA, Reichman ME. Hepatocellular carcinoma incidence, mortality, and survival trends in the United States from 1975 to 2005. J Clin Oncol. 2009;27:1485-91.

4. Siegel R, Ma J, Zou Z, Jemal A. Cancer statistics, 2014. CA Cancer J Clin. 2014;64(1):9-29.

5. El-Zayadi AR, Badran HM, Barakat EM, Attia M-D, Shawky S, Mohamed MK, et al. Hepatocellular carcinoma in Egypt: a single center study over a decade. World J Gastroenterol. 2005;11:5193-8.

6. Hassan MM, Zaghloul AS, El-Serag HB, Soliman O, Patt YZ, Chappell CL, et al. The role of hepatitis $C$ in hepatocellular carcinoma: a case control study among Egyptian patients. J Clin Gastroenterol. 2001;33:123-6.

7. Perz JF, Alter MJ. The coming wave of HCV-related liver disease:dilemmas and challenges. J Hepatol. 2006;44:441-3.

8. Si MS, Amersi F, Golish SR, Ortiz JA, Zaky J, Finklestein D, et al. Prevalence of metastases in hepatocellular carcinoma: risk factors and impact on survival. Am Surg. 2003;69:879-85.

9. Shim YS, Ahn JY, Cho JH, Lee KS. Solitary skull metastasis as initial manifestation of hepatocellular carcinoma. World J Surg Oncol. 2008;21:6-66.

10. Coban S, Yüksel O, Köklü S, Ceyhan K, Baykara M, Dökmeci A. Atypical presentation of hepatocellular carcinoma: a mass on the left thoracic wall. BMC Cancer. 2004:4:89.

11. Talapatra K, Engineer R, Agarwal JP, Vyas S, Shrivastava SK. Chest wall metastasis from hepatocellular carcinoma in the absence of a primary: an unusual presentation. J Cancer Res Ther. 2008;4:42-3.

12. Kolarević D, Tomasević Z, Boricić I, Rasić DM, Dekić NA, Milovanović Z, et al. Metastasis of hepatocellular carcinoma presented as a tumor of the maxillary sinus and retrobulbar tumor. Vojnosanit Pregl. 2011;68(4):359-62. 
13. Piccirillo M, Granata V, Albino V, Palaia R, Setola SV, Petrillo A, et al. Can hepatocellular carcinoma (HCC) produce unconventional metastases? Four cases of extrahepatic HCC. Tumori. 2013;99:e19-23.

14. Uchino K, Tateishi R, Shiina S, Kanda M, Masuzaki R, Kondo Y, et al. Hepatocellular carcinoma with extrahepatic metastasis: clinical features and prognostic factors. Cancer. 2011;117:4475-83.

15. Lasiter JC, Liess BD, Zitsch 3rd RP, Wieberg J. An expansile mandibular mass as the initial manifestation of hepatocellular carcinoma. Ear Nose Throat J. 2011;90, E19.

16. Hinojar-Gutiérrez A, Nieto-Llanos S, Mera-Menéndez F, Fernández-Contreras ME, Mendoza J, Moreno R. Laryngeal metastasis as first presentation of hepatocellular carcinoma. Rev Esp Enferm Dig. 2011;103:222-4.

17. Eldesouky MA, Elbakary MA, Shalaby OE, Shareef MM. Orbital metastasis from hepatocellular carcinoma: report of 6 cases. Ophthal Plast Reconstr Surg. 2014;30:e78-82.

18. Tomanovic N, Krstic A, Brasanac D, Dimitrijevic M, Terzic T, Boricic I. Zygomatic bone metastasis as an initial presentation of hepatocellular carcinoma. Arch Iran Med. 2013;16:675-8.

19. Budhu AS, Zipser B, Forgues M, Ye QH, Sun Z, Wang XW. The molecular signature of metastases of human hepatocellular carcinoma. Oncology. 2005;69:23-7.

20. Liaw CC, Ng KT, Chen TJ, Liaw YF. Hepatocellular carcinoma presenting as bone metastasis. Cancer. 1989;64:1753-7.

21. Yoo DJ, Kim KM, Jin YJ, Shim JH, Ko GY, Yoon HK, et al. Clinical outcome of 251 patients with extrahepatic metastasis at initial diagnosis of hepatocellular carcinoma: does transarterial chemoembolization improve survival in these patients? J Gastroenterol Hepatol. 2011;26:145-54.

22. Uka K, Aikata H, Takaki S, Shirakawa H, Jeong SC, Yamashina K, et al. Clinical features and prognosis of patients with extrahepatic metastases from hepatocellular carcinoma. World J Gastroenterol. 2007;13:414-20.

23. Fan Z, van de Rijn M, Montgomery K, Rouse RV. Hep par 1 antibody stain for the differential diagnosis of hepatocellular carcinoma: 676 tumors tested using tissue microarrays and conventional tissue sections. Mod Pathol. 2003;16:137-44.

24. Kattepur AK, Patil DB, Krishnamoorthy N, Srinivas KG, Swamy S, Amarendra $S$, et al. Isolated nasopharyngeal metastasis from hepatocellular carcinoma. Int J Surg Case Rep. 2014:5:115-7.

25. Lehman EM, Soliman AS, Ismail K, Hablas A, Seifeldin IA, Ramadan M, et al. Patterns of hepatocellular carcinoma incidence in Egypt from a populationbased cancer registry. Hepatol Res. 2008;38:465-73.

26. Liang TJ, Heller T. Pathogenesis of hepatitis C-associated hepatocellular carcinoma. Gastroenterology. 2004;127:S62-71.

27. Katyal S, Oliver 3rd JH, Peterson MS, Ferris JV, Carr BS, Baron RL. Extrahepatic metastases of hepatocellular carcinoma. Radiology. 2000;216:698-703.

28. Tang ZY. Hepatocellular carcinoma-cause, treatment and metastasis. World J Gastroenterol. 2001;7:445-54.

29. Natsuizaka M, Omura T, Akaike T, Kuwata Y, Yamazaki K, Sato T, et al. Clinical features of hepatocellular carcinoma with extrahepatic metastases. J Gastroenterol Hepatol. 2005;20:1781-7.

30. Fukutomi M, Yokota M, Chuman $\mathrm{H}$, Harada H, Zaitsu Y, Funakoshi A, et al. Increased incidence of bone metastases in hepatocellular carcinoma. Eur J Gastroenterol Hepatol. 2001;13:1083-8.

31. Daley TD, Minett CP, Driman DK, Darling MR. Oral metastatic hepatocellular carcinoma: a changing demographic in Europe and North America. Immunohistochemical advances in the microscopic diagnosis. Oral Oncol. 2011;47:62-7.

32. Olubuyide IO. Pattern of metastasis of primary liver cancer at autopsy: an African series. Trop Gastroenterol. 1991;12:67-72.

33. Pires FR, Sagarra R, Corrêa ME, Pereira CM, Vargas PA, Lopes MA. Oral metastasis of a hepatocellular carcinoma. Oral Surg Oral Med Oral Pathol Oral Radiol Endod. 2004;97:359-68.

34. Lim SY, Kim SA, Ahn SG, Kim HK, Kim SG, Hwang HK, et al. Metastatic tumours to the jaws and oral soft tissues: a retrospective analysis of 41 Korean patients. Int J Oral Maxillofac Surg. 2006;35:412-5.

35. Hirshberg A, Leibovich $P$, Buchner A. Metastases to the oral mucosa: analysis of 157 cases. J Oral Pathol Med. 1993:22:385-90.

36. Okada H, Kamino Y, Shimo M, Kitamura E, Katoh T, Nishimura H, et al. Metastatic hepatocellular carcinoma of the maxillary sinus: a rare autopsy case without lung metastasis and a review. Int J Oral Maxillofac Surg. 2003:32:97-100.

\section{Submit your next manuscript to BioMed Central and take full advantage of:}

- Convenient online submission

- Thorough peer review

- No space constraints or color figure charges

- Immediate publication on acceptance

- Inclusion in PubMed, CAS, Scopus and Google Scholar

- Research which is freely available for redistribution

Submit your manuscript at www.biomedcentral.com/submit 